MARZENA BUCHNAT*, MICHAt RZEPKA

* Uniwersytet im. Adama Mickiewicza w Poznaniu

\title{
Delfinoterapia w usprawnianiu dzieci z zaburzeniami w rozwoju - dylematy i kontrowersje
}

\begin{abstract}
Buchnat Marzena, Rzepka Michał, Dolphin-Assisted Therapy as an alternative form of support of child development - dilemmas and controversies [Delfinoterapia $\mathrm{w}$ usprawnianiu dzieci z zaburzeniami w rozwoju - dylematy i kontrowersje]. Interdyscyplinarne Konteksty Pedagogiki Specjalnej, nr 1, Poznań 2013. Pp. 73-85. Adam Mickiewicz University Press. ISBN 978-83-232-2539-3.

Dolphin-Assisted Therapy (DAT) is a form of combined therapy - aquatic therapy and animal-assisted therapy, where the patient is in close contact with the dolphin. In such therapy the dolphin is a partner, a motivator and a kind of reward for the child. It must be noted, however, that the basis of its effectiveness is the intensive child's cooperation with the therapist. During the course of professional dolphin therapy, in addition to in-water session, there are also classroom activities, where motivation and skills gained during training with the animal are used, consolidated and expanded. With such planned therapy, effects may relate to the physical as well as emotional and cognitive sphere, depending on the planned activity, which the therapist is focused on.
\end{abstract}

KEY WORDS: dolphin-assisted therapy, support of child development, effectiveness

Delfinoterapia, jeden z rodzajów animalterapii, wzbudza wiele kontrowersji, które dotyczą głównie efektywności tego rodzajów terapii. Trudno rozstrzygnąć, czy bardziej znaczący wpływ na jej efekt ma samo zwierzę biorące $\mathrm{w}$ niej udział, czy terapeuta kon- 
struujący program. Delfiny mają wiele cech sprzyjających ich wykorzystaniu do terapii, jednak to nie wystarczy, by uzyskać pożądane wyniki - jak w każdej innej formie wsparcia rozwoju potrzebna jest praca, jaką musi wykonać mały pacjent.

Delfinoterapia nie jest w Polsce dostępna. Osoby, które chcą z niej skorzystać, muszą udać się do jednego z (i tak nielicznych) ośrodków za granicą. Jednocześnie wzbudza ona, zwłaszcza wśród rodziców dzieci z niepełnosprawnością, wiele emocji i oczekiwań, nie zawsze korespondujących z jej faktycznymi możliwościami wsparcia rozwoju. Artykuł ten kierujemy do osób, które chciałyby bliżej poznać to zagadnienie, w szczególności do terapeutów, nauczycieli, studentów oraz rodziców dzieci wymagających wsparcia. Jest on próbą prezentacji (opartej na dostępnej literaturze przedmiotu oraz doświadczeniach jednego z wiodących ośrodków delfinoterapii Island Dolphin Care z Key Largo na Florydzie - IDC) istoty delfinoterapii oraz kluczowych czynników sprzyjających odniesieniu, na jej skutek, sukcesu terapeutycznego.

Pierwsza część tekstu poświęcona jest definiowaniu pojęcia "delfinoterapia”, które nie doczekało się do tej pory naukowego sprecyzowania i jest dziś stosowane bardzo szeroko, często w dość potocznym rozumieniu. Następnie postaramy się przybliżyć istotę delfinoterapii i obszary, w jakich może ona stanowić skuteczną formę wsparcia rozwoju dziecka z niepełnosprawnością. Na koniec, $\mathrm{w}$ formie swoistego case study, zaprezentujemy delfinoterapię w praktyce, opierając się na doświadczeniach i programie IDC.

\section{Delfinoterapia - próba definicji}

W najbardziej precyzyjnym ujęciu delfinoterapia (Dolphin-Assisted Therapy - DAT) to forma połaczonej terapii - aquai animaloterapii - podczas której pacjent znajduje się w bliskim kontakcie $\mathrm{z}$ delfinem. Badania nad wykorzystywaniem delfinów do terapii dzieci cierpiących na choroby psychiczne i fizyczne rozpo- 
częli w latach 70. amerykańscy naukowcy i neuropsychiatrzy z Uniwersytetu w Miami. Za twórcę tej metody uznano amerykańskiego psychologa Dawida Nathansona (1978) ${ }^{1}$.

Terapia polega na wspólnym pływaniu i zabawie, podczas której osoby niepełnosprawne wykonują szereg, dostosowanych do indywidualnych potrzeb i możliwości, ćwiczeń z udziałem delfinów. Ćwiczenia te przyjmują jednak charakter zabawy, dzięki czemu chore lub niepełnosprawne dzieci nieświadomie uprawiają najbardziej efektywną gimnastykę ruchową. Na dodatek dziecko zamienia gabinet lekarski czy salkę do ćwiczeń, kojarzoną ze żmudnymi, wciąż powtarzanymi, często nudnymi ćwiczeniami, na basen. Zamiast fizjoterapeuty pojawia się delfin, zawsze chętny do zabawy, z budzącym sympatię, a wynikającym z jego anatomii, uśmiechem.

W czasie tych zabaw możliwy jest nie tylko kontakt fizyczny $z$ delfinem, ale również pacjent wystawiony jest na działanie emitowanych przez delfiny sygnałów echolokacji i wiązek ultradźwięków, które, jak uważa część zwolenników tej formy terapii, przenikając ludzkie tkanki, oddziałują na układ neurobiologiczny i hormonalny. Podczas zabawy z delfinami zwiększa się u człowieka wydzielanie endorfin, czyli naturalnych substancji produkowanych przez przysadkę mózgową. Endorfiny zmniejszają odczucie bólu, głodu, ułatwiając oddychanie, wpływają na termoregulację oraz wydzielanie się różnych hormonów. Takie dobroczynnie działanie wpływa na funkcjonowanie i aktywizację osób z zaburzeniami rozwoju.

Ze względu na środowisko, w jakim terapia się odbywa, delfinoterapia łączy w sobie elementy innych form wsparcia, jak choćby hydroterapii. Zajęcia odbywają się w wodzie, która sprzyja relaksacji, odprężeniu ludzkiego ciała, co ma znaczenie dla podniesienia efektywności rehabilitacji ruchowej. Sam twórca mówił o swojej metodzie, że powoduje skokową poprawę u dzieci z autyzmem, mózgowym porażeniem dziecięcym lub zespołem Downa.

${ }^{1}$ D.E. Nathanson, Rusing Atlantic Bottlenose Delphins to Increase Cognition of Mentalny Retarded Children, "Clinical and Abnormal Psychology" 1989, 1(6), s. 233-242. 


\section{Dylematy i kontrowersje związane ze skutecznością delfinoterapii}

Dolphin-Assisted Therapy (DAT) może być wykorzystywana zarówno do celów ogólnorozwojowych, czyli dla poprawy ogólnego stanu zdrowia, na przykład psychicznego, jak i do celów terapeutycznych. Zaburzenia i choroby, w których ta forma terapii przynosi najlepsze rezultaty, to: mózgowe porażenie dziecięce, autyzm, zespół Downa, inne zaburzenia genetyczne, ADHD, zaburzenie czynnościowe centralnego systemu nerwowego, niepełnosprawność intelektualna, zaburzenia mowy i słuchu, głuchota nerwowo-sensorowa, nerwice, zaburzenia stresowe pourazowe, zaburzenia depresyjne o charakterze nieendogennym, zaburzenia pamięci, zaburzenia w przyswajaniu wiedzy, zaburzenia psychiczne. Aby terapia przyniosła jak największą efektywność, dziecko powinno trafić do ośrodka w wieku od 7 miesięcy do 6 lat² $^{2}$ Na świecie działają tylko trzy takie centra, między innymi na Ukrainie i w USA.

Badania nad efektywnością tej terapii zapoczątkowane były pracami D. Nathansona (1997-1998)3 oraz L. Lukiny (1999)', w których potwierdzono jej skuteczność. Przeprowadzona w 2007 r., przez dr L. Marino, analiza metodyki tych badań, ich rzetelności oraz trafności wskazuje jednak na szereg nieścisłości metodologicznych, uproszczeń i stwierdzeń nieuzasadnionych z punktu widzenia naukowego, co $\mathrm{w}$ znaczący sposób podważa zaprezentowane wyniki 5 . W tym samym niemal czasie (pod koniec 2006 r.) sceptycz-

2 E. Breitenbach, E. Stumpf, L. v. Fersen, H. Ebert, Hoffnungsträger Delfin. Mögliche Effekte und Wirkfaktoren tiergestützter Therapie bei Kindern mit Behinderungen, aufgezeigt am Beispiel der Delfintherapie, „Geistige Behinderung” 2004, 43(4), Verfügbar, s. 339-357.

3 D.E. Nathanson, Long-term effectiveness of dolphin assisted therapy for children with severe disabilitie, "Anthrozoos" 1998, 11(1), s. 22-32.

${ }^{4}$ L. Lukin, Influence of Dolphin-Assisted Therapy Sessions on the Functional State of Children with Psychoneurological Symptoms of Diseases, "Human Physiology" 1999, Vol. 25, No. 6, s. 676.

${ }^{5}$ L. Marino, S. Lilienfeld, Dolphin-assisted therapy: flawed data, flawed conclusions, "Anthrozoos" 2007, 20(3), s. 239-249. 
nie wypowiedziało się niemieckie stowarzyszenie "Autyzm”, oficjalnie oznajmiając, że nie ma żadnych przekonywujących dowodów na to, że delfinoterapia jest skuteczną formą leczenia autyzmu ${ }^{6}$.

Do tej pory nie przeprowadzono wiarygodnych naukowo badań, które dostarczyłyby dowodów na efektywność tej formy leczenia w zakresie wpływu emitowanych przez delfiny ultradźwięków czy sygnałów echolokacyjnych7 ${ }^{7}$. To implikuje stwierdzenie, że kontakt $\mathrm{z}$ delfinem stanowi dodatkowy element wzmacniający terapię, która opiera się na pracy terapeuty z dzieckiem i przeważnie obecną podczas zajęć rodziną. Dlatego efekty delfinoterapii nie odnoszą się jedynie do sfery ruchowej, ale także społecznej, emocjonalnej czy poznawczej, w zależności od tego, na której z tych sfer koncentruje się zaplanowane działanie terapeuty. Obecnie dopuszczalne jest stwierdzenie, że delfinoterapia, łącząca w sobie elementy między innymi hydroterapii czy fizjoterapii, może przynosić pozytywne skutki, głównie jednak pod kątem obecności zwierzęcia jako motywatora, który stymuluje dziecko do działania.

Wykorzystanie $\mathrm{w}$ celach terapeutycznych delfina jest uwarunkowane: jego naturalnymi właściwościami: połączeniem wysokiego intelektu tego zwierzęcia i unikalnych cech fizycznych (głównie budzącego sympatię wyglądu), zdolnością do obcowania między gatunkami, zabawowym zachowaniem się.

${ }^{6}$ Pod koniec 2006 r. niemieckie Stowarzyszenie „Autyzm”, w swoim oświadczeniu dla mediów z dnia 12 października, oficjalnie stwierdziło, że nie ma żadnych przekonywujących dowodów na to, że delfinoterapia jest skuteczną formą leczenia autyzmu. Prezes stowarzyszenia Maria Kaminski, ustosunkowując się do tematu wciąż rosnącej popularności terapii z udziałem delfinów w delfinariach, wyjaśniła: „Pomimo przeprowadzenia intensywnych badań, wciąż nie ma naukowych dowodów na to, że terapia z udziałem delfina pomaga leczyć dzieci autystyczne. Aby zapewnić im pomoc Stowarzyszenie rekomenduje konsekwentne działania edukacyjne, terapię behawioralną zawierającą ćwiczenia mowy i zachowań społecznych. Delfiny to dzikie zwierzęta. To już kwestia etyki, czy wolno nam pozbawiać je wolności, by wykorzystywać je do tak wątpliwych działań" (Kaminski, 2006, <http:// www.czydelfinoterapia.pl/> [dostęp: 01.10.2012]).

7 K. Brengsing, K. Linke, D. Todt, Can Dolphins heal by ultrasound?, "Journal of Theoretical Biology" 2003, 225, s. 99-105. 
Taka analiza dokonywana jest jednak z punktu widzenia przydatności zwierząt dla ludzi. Obrońcy praw zwierząt wskazują na ewidentne naruszenie dobrostanu dzikich zwierząt, które mają samoświadomość, tworzą bogate więzi społeczne i są w stanie odczuwać takie stany, jak cierpienie czy stres, nie tylko na poziomie fizjologicznym ${ }^{8}$. Wyniki ostatnio przeprowadzonych badań, odnoszących się do efektywności delfinoterapii, podtrzymują sceptycyzm wobec skuteczności tej terapii i podkreślają etyczny problem nieuzasadnionego wykorzystywania dziko żyjących zwierząt ${ }^{9}$, wskazując, że podobne wyniki można osiągnąć za pomocą zwierząt udomowionych. Jak to określił Gary Francione:

[...] w rzeczywistości nasze społeczeństwo traktuje zwierzęta w sposób, w jaki traktuje się każdą inną formę własności. Jeśli jednak traktowalibyśmy zwierzęta według tego jednego prawa do nie bycia traktowanym jako własność, bylibyśmy zobowiązani do obalenia, a nie jedynie uregulowania wyzysku zwierząt (Wychowałek 2002) ${ }^{10}$.

\section{Delfinoterapia w praktyce - doświadczenia Island Dolphin Care}

Ośrodki na światowym poziomie nie tylko umożliwiają delfinom warunki życia jak najbardziej zbliżone do naturalnych, ale przede wszystkim traktują je jako współpracowników, z określonymi prawami, na przykład do wypoczynku. Do takich ośrodków należy właśnie Island Dolphin Care (IDC). Zadbano tam przede wszystkim o stworzenie godnych warunków życia delfinom-tera-

${ }^{8}$ D.R. Griffin, Umysty zwierząt, przeł. M. Ślósarska i A. Tabaczyńska, GWP, Gdańsk 2004, s. 18-20.

${ }^{9} \mathrm{~K}$. Brensing, Swim with the dolphin programs and "Dolphin-assisted therapy", $<$ http:/ / faada.org/userfiles/Brensing \%20Expert\%20Statement $\% 20$ SWTD $\% 20$ Accob ams\%202005.pdf/> [dostęp: 26.10.2012].

${ }^{10} \mathrm{~J}$. Banasiak, DELFINOTERAPIA - konflikt interesów cztowieka i zwierzęcia?, $<$ http://www.dogoterapeuta.wortale.net/180-DELFINOTERAPIA-konflikt-interesowczlowieka-i-zwierzecia.htm/> [dostęp: 26.10.2012]. 
peutom. Ich akwen w IDC to odnoga kanału połączonego z oceanem - jest więc to ich naturalne środowisko, w którym woda podlega takim samym pływom, jakim podlega ocean. W IDC, które jest pod stałym nadzorem instytucji zajmujących się prawami zwierząt, rygorystycznie przestrzega się ich ustawowych praw i zwraca szczególną uwagę na ich komfort oraz bezpieczeństwo. Wszyscy zdają sobie sprawę, że one są tak samo ważne, jak pacjenci. Delfiny mają stałą opiekę weterynaryjną, regulowany czas pracy (do 2 godz. dziennie), odpowiednio dobraną dietę. To, że delfiny czują się tam dobrze, najlepiej poświadcza fakt, że swobodnie się rozmnażają i w ciągu ostatnich dwóch lat dwukrotnie przyszedł tam na świat nowy delfin.

Ośrodek Island Dolphin Care (IDC) zapewnia przede wszystkim komfort i bezpieczeństwo dzieciom, które przebywają $\mathrm{w}$ nim na terapii. Ze względu na warunki klimatyczne woda jest ciepła, dzieci mogą jednak, w razie potrzeby, korzystać z neoprenowych pianek do pływania oraz, obowiązkowo, z kamizelek - kapoków. Do wody schodzi się z zacienionych płóciennym daszkiem, chroniącym od słońca, platform, które zacumowane są do pomostu. Ośrodek dysponuje własnym dwupiętrowym budynkiem wyposażonym w windę dla osób z niepełnosprawnością. Na pierwszym piętrze znajdują się biura, recepcja, hol oraz łazienki i przebieralnie dla dzieci biorących udział w terapii, a także dwie klasy, w których odbywają się zajęcia terapeutyczne (cała infrastruktura ośrodka dostosowana jest do potrzeb osób z niepełnosprawnością). Na drugim piętrze jest sala spotkań oraz kolejne klasy ćwiczeniowe i pokój, w którym rodzina dziecka przebywającego na terapii może skorzystać z komputera, Internetu czy podręcznej, fachowej biblioteczki.

Klasy, w których odbywają się zajęcia, są przestronne, widne, z dużymi oknami, stołami do pracy, umywalką, zapleczem plastycznym i rekreacyjnym oraz sprzętem potrzebnym w czasie zajęć, w tym specjalnymi komputerami z dotykowym ekranem i oprogramowaniem do wspierania komunikacji z dziećmi, które nie potrafią mówić lub nie słyszą. Na tyłach budynku znajduje się teren, na którym jest zarówno akwen do terapii w wodzie, jak i touch tank 
- specjalne akwarium z różnymi zwierzętami morskimi, które dzieci, podczas prowadzonych w IDC zajęć związanych $\mathrm{z}$ ekologią i ochroną mórz, mogą oglądać z bliska, dotykać czy brać do ręki (np.: gąbki, rozgwiazdy, ślimaki morskie, strzykwy i szkarłupnie, kraby i wiele innych), oraz pełen dźwięków i kolorów ogród sensoryczny. W ICD zatrudnieni są specjaliści, którzy nie tylko są przeszkoleni w pracy z delfinami, ale przede wszystkim są wykształconymi i doświadczonymi terapeutami.

Terapia w Island Dolphin Care zorientowana jest na potrzeby każdego dziecka z osobna. Cele terapii wyznaczane są z uwzględnieniem jego możliwości, do których dostosowane są ćwiczenia i zajęcia. Terapia oparta jest na indywidualnych zajęciach w wodzie oraz uzupełniających indywidualnych zajęciach w klasie.

W czasie zajęć w wodzie wykonywanych jest kilkanaście różnych ćwiczeń z delfinem, więc fizyczny kontakt ze zwierzęciem jest ciągły, dziecko dotyka delfina, trzyma za płetwy, głaszcze, pływa na brzuchu delfinów itp. W czasie zajęć w klasie dziecko bawi się i ćwiczy, na przykład wykonując i ozdabiając różne przedmioty. Praca opiera się na wrażeniach sensorycznych, ale także na emocjach, by dziecko rozwinęło, w zależności od wyznaczonych celów terapii, umiejętności związane z komunikowaniem się lub usprawnianiem ruchowym. Terapia, której przypisany jest blok zajęć w wodzie oraz w klasie, jest bardzo intensywna, a dzięki indywidualnemu planowaniu nieustannie dostarcza dzieciom okazji, by ćwiczyć różne umiejętności, co implikuje efektywność jej prowadzenia.

W ciągu dnia odbywają się tylko dwie sesje, z których w każdej uczestniczy czworo dzieci po kolei, więc w tygodniu w terapii $\mathrm{w}$ sumie udział bierze ośmioro dzieci. Bezpośrednio z każdym dzieckiem pracuje jeden terapeuta i dwóch wolontariuszy, ale cały zespół komunikuje się z sobą i omawia wszystkie przypadki. Zatem każdy z terapeutów ma świadomość, jak dane dziecko pracuje, co umie, co osiągnęło, z czym ma problemy. Plany terapii dla każdego dziecka ustalane są zespołowo. Ważnym elementem terapii jest komunikacja z rodzicami lub opiekunami i włącznie ich, na ile jest to możliwe, w proces terapii. Terapeuci po zakończonych w danym 
dniu zajęciach omawiają z rodzicami ich przebieg, wskazują na osiągnięcia i ustalają zadania na następną sesję. Dzięki takiej komunikacji rodzice mogą się bardziej zaangażować w przebieg terapii w ośrodku, ale mogą również kontynuować ją, choćby fragmentarycznie, po powrocie do domu. Terapeuci nie tylko realizują ustalony plan terapii, ale przede wszystkim obserwują dziecko, zbierają sygnały od rodziców, by móc stale dostosowywać program do aktualnych potrzeb pacjenta ${ }^{11}$.

Program terapii w IDC opracowany został jako moduł trwający pięć dni. Dokonując rezerwacji, należy podjąć decyzję, w ilu takich tygodniowych modułach dziecko ma brać udział.

Od poniedziałku do czwartku terapia składa się z dwóch komponentów: zajęć w wodzie i zajęć w klasie. Obie te formy zajęć, jak wspomniano, są indywidualne. Każdego dnia zajęcia planowane są rano lub po południu, w każdej z tur udział bierze czworo dzieci. W zależności od planu zajęcia mogą zaczynać się od terapii w wodzie, a następnie kontynuowane są w klasie lub odwrotnie - kolejność nie odgrywa tu żadnej roli.

Terapia w wodzie jest wyjątkowa. Bierze w niej udział dziecko wraz z terapeutą i delfinem. Rodzice, jeśli to konieczne, mogą znajdować się na platformie, na której jest również trener delfinów, wydający im polecenia, oraz dwóch stażystów do pomocy (jeden pomaga terapeucie, podając potrzebne przedmioty do ćwiczeń, drugi zaś prowadzi dokumentację fotograficzną $\mathrm{i}$ opis terapii $\mathrm{w}$ danym dniu). Z jednym dzieckiem pracuje, więc czterech dorosłych.

Wszystkie zajęcia w wodzie prowadzone są pod kątem wyznaczonego celu. Może nim być usprawnianie fizyczne, może również wsparcie komunikacji. Zestaw ćwiczeń wykonywanych z delfinem dla obu tych celów jest taki sam. Zajęcia polegają na pracy dziecka: czy to aktywności ruchowej, czy wsparcia komunikacji itp. W pracy nad rozwojem umiejętności komunikacyjnych to dziecko dokonuje wyboru „zabawy” z delfinem, wskazując swój wybór, na przy-

115 Day Dolphin Time-Out Program, <http://www.islanddolphincare.org/ program-2/5-day-therapy-program//> [dostęp: 26.10.2012]. 
kład, na odpowiednio przygotowanych tabliczkach z symbolami, wskazując ćwiczenie, korzystając $\mathrm{z}$ odpowiednich gestów, czy komunikując się werbalnie. Wybieranie ćwiczenia z zestawu zaplanowanego przez terapeutę jest motywowane nagrodą, jaką dla dziecka jest wybrana przez nie zabawa $\mathrm{z}$ delfinem. Zajęcia $\mathrm{w}$ wodzie trwają $30-45 \mathrm{~min}$. W tym czasie dziecko wykonuje od kilku do kilkunastu różnych ćwiczeń. Czas ten jest wystarczający, ponieważ dzieci szybko się męczą, na co wpływ ma nie tylko sama aktywność fizyczna w wodzie, ale również liczne emocji, które jej towarzyszą.

Zajęcia w klasie to dalszy ciąg pracy nad wyznaczonym celem. $W$ tej części terapii z jednym dzieckiem pracuje przynajmniej trzech dorosłych - terapeuta oraz dwóch stażystów. Pretekstem do ćwiczeń są różne formy zabawy, na przykład zajęcia plastyczne lub muzyczne. Dodatkowo dzieciom dostarczane są rozmaite bodźce sensoryczne, podczas zajęć wykorzystuje się materiały o różnej konsystencji i fakturze - dziecko maluje zarówno rękoma, jak i pędzelkami czy kredkami, bawi się ciastoliną, przesypuje sypkie produkty itp.

Efektem zajęć w klasie są również wykonane, w znacznej części samodzielnie, przez dziecko „produkty”, m.in.: malowany T-shirt, malowane i ozdabiane pieczątkami podkładki pod talerze, książka o swoim pobycie w IDC wraz ze zdjęciami i wykorzystywanymi PCS-ami, tamburyn, ciasto $\mathrm{z}$ kremem itd. $\mathrm{W}$ czasie tych zajęć dziecko, w zależności od wyznaczonego celu, motywowane jest do ciągłego dokonywania i komunikowania wszelkich wyborów (co chce robić, czym chce ozdabiać, jakie kolory wybiera w danym momencie itp.). Liczba wyborów, jakich musi dokonać dziecko podczas zajęć, jest ogromna. Taka intensywność i liczba powtórzeń pozwalają uzyskać założony efekt terapii.

Czwartek w IDC jest tak zwanym dniem rodzeństwa, kiedy jedno $\mathrm{z}$ rodzeństwa może wraz z pacjentem, swoim bratem lub siostrą, brać udział $\mathrm{w}$ zajęciach $\mathrm{w}$ wodzie. Jeśli obecność rodzeństwa podczas zajęć $\mathrm{w}$ klasie nie stanowi przeszkód $\mathrm{w}$ realizacji planu terapii, może ono także uczestniczyć w zajęciach w klasie każdego dnia. 
W piątek nie ma zajęć w klasie, a zajęcia w wodzie odbywają się rano - tak zwany natural swimming. Jest to wyjątkowa sytuacja, kiedy podczas swobodnego pływania każdemu dziecku, będącemu w danym tygodniu na terapii, towarzyszy jeden rodzic. Naturalne pływanie daje możliwość bliskiego obcowania z delfinami, jednocześnie dla rodziców jest to również emocjonujące przeżycie.

Dokonywana przez stażystów dokumentacja terapii w postaci szczegółowych opisów i fotografii po jej zakończeniu jest dostępna dla rodziców ${ }^{12}$. Dokumentacja ta jest niebagatelną pomocą w kontynuacji założeń terapii po powrocie do domu.

\section{Skuteczność delfinoterapii}

Efektywność delfinoterapii zależy przede wszystkim od pracy, jaką wykona dziecko z terapeutą, od tego, na ile zaplanowana terapia była odpowiednio dostosowana do potrzeb i możliwości dziecka. Delfin jest czynnikiem wspierającym terapię. Wpływając na motywację dziecka, zwiększa się efektywność jego pracy, a zarazem podnosi jakość przeprowadzonej terapii.

$\mathrm{W}$ pracy z dziećmi z niepełnosprawnością delfin spełnia przede wszystkim funkcję motywującą. Możliwość zabawy z tym budzącym ogromną sympatię zwierzęciem jest nagrodą. Zwierzę może jednak również przyjąć rolę pomostu $\mathrm{w}$ nawiązywaniu kontaktu $\mathrm{z}$ terapeutą czy innymi osobami, co jest szczególnie cenne w pracy z dziećmi z zaburzoną komunikacją, na przykład autystycznymi. Praca z delfinami wywołuje u dzieci pozytywne emocje, które ułatwiają proces koncentracji na zadaniu. Zabawa z tymi ssakami może budzić też obawę. Jednakże przełamywanie jej pozwala dziecku na zdobycie cennych doświadczeń, które budują nowe kompetencje rozwojowe. Delfinoterapia stawia dziecko, za każdym razem, w nowej sytuacji, zmusza do wypróbowania swoich nowych zachowań, co pozwala na zdobycie nowej wiedzy o sobie samym, i to zarówno w obszarze ruchowym, jak i w obszarze emocjonalnym czy społecznym. Pobyt

12 Tamże. 
dziecka w wodzie oraz bezpośredni kontakt z delfinem wspierają jego rozwój fizyczny głównie w zakresie: koordynacji ruchowej, wzmocnienia mięśni, zahamowania odruchów patologicznych, stabilizacji ciała, jak i budowania jego świadomości. Rozwój świadomości własnego ciała warunkuje jego samokontrolę. Doświadczenia, jakie zdobywa dziecko podczas terapii, to dostrzeganie związku pomiędzy działaniem i jego skutkiem, co w znaczący sposób wspiera rozwój myślenia. Polisensoryczne poznanie, powiązane z przeżywanymi emocjami, w znaczący sposób podnosi efektywność zapamiętywania. Akceptacja, jakiej doznaje dziecko od zwierzęcia, wzmacnia jego poczucie wartości ${ }^{13}$.

Istotnym czynnikiem przemawiającym za delfinoterapią jest także obecność w czasie jej trwania członków rodziny. Dla dzieci rodzina stanowi najważniejszy system wsparcia. Podczas terapii, w którą są zaangażowani rodzice, często również rodzeństwo, dochodzi do polepszenia wzajemnych relacji. Wspólne pływanie z delfinami może okazać się jedną z nielicznych aktywności, która w równym stopniu jest atrakcyjna dla wszystkich i całej rodzinie dostarcza tak wiele pozytywnych przeżyć. Podczas terapii w klasie rodzice mają możliwość nauczenia się nowych form pracy z dzieckiem, ale przede wszystkim, przy wsparciu terapeuty, lepszego zrozumienia funkcjonowania swojego dziecka. To pozwala na pełną akceptację dziecka i obiektywizację stawianych mu wymagań.

Efektywność delfinoterapii, jako jedna z alternatywnych form wspierania rozwoju dziecka, zależy głównie od jej profesjonalnego przygotowania. Terapia, zaplanowana przez specjalistów indywidualnie, pod kątem możliwości i potrzeb danego dziecka, jest połączeniem zajęć ze zwierzęciem w wodzie z zajęciami w klasie we współpracy z rodzicami - na pewno będzie skuteczna. O jej jakości zadecydują trafnie ustalone cele i praca, jaką wykona dziecko.

${ }^{13}$ E. Breitenbach, L. v. Fersen, E. Stumpf, H. Ebert, Delfintherapie für Kinder mit Behinderungen. Analyse und Erklärung der Wirksamkeit, Edition Bentheim, Würzburg 2006; T.L. Humphries, Effectiveness of Dolphin-Assisted Therapy as a Behavioral Intervention for Young Children with Disabilities, "Bridges" 2003, Vol. 1, No. 6; D. Grabczan, Zasadność terapii kontaktowej ludzi z udziałem delfinów butlonosych, SWPS, Warszawa 2008. 


\section{Bibliografia}

BANASIAK J., DELFINOTERAPIA - konflikt interesów cztowieka i zwierzęcia?, <http:// www.dogoterapeuta.wortale.net/180-DELFINOTERAPIA-konflikt-interesow-czlo wieka-i-zwierzecia.htm/> [dostęp: 26.10.2012].

BREITENBACH E., STUMPF E., V. FERSEN L., EBERT H., Hoffnungsträger Delfin. Mögliche Effekte und Wirkfaktoren tiergestützter Therapie bei Kindern mit Behinderungen, aufgezeigt am Beispiel der Delfintherapie, "Geistige Behinderung" 2004, 43(4), s. 339-357.

BREITENBACH E., V. FERSEN L., STUMPF E., EBERT H., Delfintherapie für Kinder mit Behinderungen. Analyse und Erklärung der Wirksamkeit, Edition Bentheim, Würzburg 2006.

BRENGSING K., LINKE K., TODT D., Can Dolphins heal by ultrasound?, “Journal of Theoretical Biology" 2003, 225, s. 99-105.

BRENSING K., Swim with the dolphin programs and "Dolphin-assisted therapy", <http://faada.org/userfiles/Brensing\%20Expert\%20Statement\%20SWTD\%20A ccobams\%202005.pdf/> [dostęp: 26.10.2012].

GRABCZAN D., Zasadność terapii kontaktowej ludzi z udziałem delfinów butlonosych, SWPS, Warszawa 2008.

GRIFFIN D.R., Umysty zwierząt, przeł. M. Ślósarska i A. Tabaczyńska, GWP, Gdańsk 2004, s. 18-20.

<http:// www.czydelfinoterapia.pl/> [dostęp: 01.10.2012].

<http://www.islanddolphincare.org/program-2/5-day-therapy-program//> [dostęp: 26.10.2012].

HUMPHRIES T.L., Effectiveness of Dolphin-Assisted Therapy as a Behavioral Intervention for Young Children with Disabilities, "Bridges" 2003, Vol. 1, No. 6.

LUKIN L., Influence of Dolphin-Assisted Therapy Sessions on the Functional State of Children, with Psychoneurological Symptoms of Diseases, "Human Physiology" 1999, Vol. 25, No. 6, s. 676.

MARINO L., LILIENFELD S., Dolphin-assisted therapy: flawed data, flawed conclusions, "Anthrozoos" 2007, 20(3), s. 239-249.

NATHANSON D.E., Long-term effectiveness of dolphin assisted therapy for children with severe disabilitie, "Anthrozoos" 1998, 11(1), s. 22-32.

NATHANSON D.E., Rusing Atlantic Bottlenose Delphins to Increase Cognition of Mentalny Retarded Children, "Clinical and Abnormal Psychology" 1989, s. 233-242.

ZAORSKA M., Delfinoterapia, [w:] J. Pańczyk (red.), Forum Pedagogów Specjalnych XXI wieku, Uniw. Łódzki, Łódź 2002, s. 306-317. 